\title{
Ceridwen Dovey's Only the Animals and the Politics of Re-interventions on Anthropocentrism
}

\author{
Habibur Rahaman \\ Department of English, Bangabandhu Sheikh Mujibur Rahman Science and Technology University, Bangladesh
}

\begin{abstract}
This article ascertains how Ceridwen Dovey's Only the Animals (2014) aligns with interdisciplinary studies which critique anthropocentric binaries of human-nonhuman relationships. Drawing on a critical analysis of the selected stories of the book, this article attempts a broader study of Dovey's book. Dovey's ten stories are, as the article argues, a radical re-narrativisation against human-nonhuman binaries lying in the creative-cultural human world. It also sees the book as a subversive interrogation of human superiority. The ten animals of this book, then, are not mere metaphoric or symbolic embodiments of human sufferings, rather they represent an autonomous world of beings. These beings, as Dovey projects, challenge the human world's cultural and creative ways of using and subjugating nonhuman beings to consolidate a human-centric world system. This article hinges on this aspect of the assertive nonhuman identity vis-à-vis the human identity, in particular, and then theoretically underpins Dovey's book's significance through some ecocritical and posthuman lenses.
\end{abstract}

Index Terms - human-nonhuman binaries, re-narrativisation of human-nonhuman relationship, ecocriticism and post-humanism

\section{INTRODUCTION}

A repertoire of ten animal-centered stories, Only the Animals, is a revisionary work of Ceridwen Dovey. This animalcentric fiction revolves around souls of ten deceased animals who got killed in ten wars of human civilisation. It alludes to ten authors writing on the "animal question" (Derrida, cited in Dönmez, 2016, pp.105-15). Epiphanic and provocative, the stories deal with ten human wars spanning from 1892 to 2006, e.g., from frontier battles of Australia to Israel-Hezbullah war, and revisits human form of narratives on nonhuman beings. It also correspondingly debunks the Renaissance-Enlightenment formation of human beings as a subjective, sovereign and self-sustained being or center of the world. Vastly allusive, each story also attaches a critical tribute to writers, e.g., among others George Orwell, Franz Kafka, and Tom Stoppard, who have written on animal subject-matters, and defamiliarizes our human gaze on animals or nonhuman being towards a subversive animal gaze. Interestingly, Dovey, through her ten animal psyches, pokes some ironies on how even literature without nonhuman or animal presence would be an incomplete cultural production. Her exploitation of animal perspectives and invocation of the writers, who have used animal imageries to pen some prominent pieces of literature, delineate how human world has objectified and depended on nonhuman world.

The book relates ten stories of ten animals, with distinct animal voices, and begins with the dates ten animals died in different human wars around the world. All these haunting but intellectualising animal memoirs subvert previous socioethico-cultural-literary attempts to empathise "occluded histories and perspectives" (Langdon 2016) and issue some posthuman critiques of the universalised human superiority ideals, as they are propounded by Kantian-Hegelian the "the human/the subject" nexus (Wolfe, cited in Moore, 2014, p.17-35). Dovey vehemently questions this us-other binary practiced against animals and calls for a radical revision to this continued indulgence of deanimalisation through a narrative of "more complex and rational subject formed by embodiment, affectivity, empathy and desire as core qualities" (Braidotti, cited in Dönmez, 2016, p.108). Self-reflexive, as postmodern fictions are, these stories do not push us to believe that they metaphorically, or symbolically, or allegorically stand for the downtrodden humans. This is the way animals have been exploited, appropriated and debased by the cultural practices: they have been presented to represent human, but not the vice versa. These stories, however, tease human insensitivity to animals. Dovey has accomplished in her animal narratives which are supremely eco-ethical and posthuman. This paper resonates with Dovey's eco-political stance that espouses the idea that nonhumans should be reconsidered and be heard with creativecritical sensitivity and understanding.

This paper elucidates how Ceridwen Dovey's Only the Animals (2014) can be critically applied to critique creative and practical human treatments of the nonhuman beings. It discusses human-nonhuman boundaries existing in our creative-cultural continuum and endeavours to establish how Dovey's animal narratives reflect a through-going posthuman, ecocritical and animal studies perspective. In doing so, this paper hinges on selected underpinnings of posthumanism, ecocriticism, animal studies and postmodernism. This paper does not scan the book allegorically or symbolically and proposes no fixed interpretation, rather explores Dovey's strengths of animal narratives with crossdisciplinary references to posthumanism, postmodernism, ecocriticism and animal studies. 


\section{LITERATURE REVIEW}

Though there are some critical studies on Dovey's Only the Animals, there lies a spotlight on Dovey's experimental story-telling and narrativisations of animal perspectives. They have stressed on the radical newness in the narrative style of her stories. As Ivan Callus (2014, p.119) examines, experimental stories represent "the new", that "then, is newly possible". Callus further notes that "the really new might be upon us, around the corner, about to happen, fresh and bright for the encounter, coming smartly and soon to a 'page' near you." David Herman (2012, pp. 93-119) thinks that "this approach to animal autobiography forms part of the larger project of developing a narratology beyond human". He further maintains that "possibilities of animal autobiography, and into how this narrative mode bears on author-principal relationships both across and within the species boundary." (Herman, 2016, p.17) S. Kirk Walsh (2015) dealing with some stories of this collection, e.g., "The Bones", "Psittacophile" and so on celebrates the strengths of Dovey's "ability to create distinctive first-person voices for the animals of her menagerie - voices that are at once human, playful and sad". Leigh Dale acclaims this book as an "intellectualized writing" having profound "attractions", "theorizing" and "reflection" along with a "conjunction of death, animality and the problem of telling stories." (Dale, 2014, pp. 36\&40). He, however, critiques Dovey pinpointing her extreme insistence on 'form' with no care given to 'the ending' and suspects if her animal-ethics will truly "focus our attention to animal death". (2014b) All these studies deal with Dovey's subversive re-narrativization of animal subjectivity but have sidestepped the far-ranging capacities and theoretically stimulating articulations, i.e., posthumanist and ecocritical and animal studies implications of the book.

This paper undertakes both textual and theoretical investigations to make a bridge between Only the Animals and ecocriticism and posthumanism. To do so, it critically refers to some stories of this text which are "The Bones", "A Letter to Sylvia Plath" and "Psittacophile", "Red Peter's Little Lady" and "Hundstage". These stories centre on the souls of a camel, a dolphin, a parrot, a chimpanzee and a dog respectively. The camel died in 1892 in the frontier war of Australia, the dolphin in 2003 in the USA invasion in Iraq, the parrot in 2006 in the Israel-Hezbollah war, the chimpanzee in the Nazi war in Germany and a dog in the First World War. The close reading of these stories delineates how animal perspectives on violence and vulnerability, which is constantly unleashed on non-human world by the human world, remain unexplored in our creative-critical world. This angle of the text connotes ecocritical and posthumanist theories reflected in this text.

\section{ECOCRITICISM DEFINED AS IT RELATES TO LITERARY STUDIES}

Ecocriticism is an inter-disciplinary study, given that it has its alignments with literature, philosophy, science, geography, politics and global economics. But in this paper I will concentrate, in particular, on how ecocriticism is a very political and subversive study of nature, as it fundamentally relates to literature, or literary culture at length. This paper explores the theo-critical affiliations that ecocritical study of literature emanates. This angle of discussions hinge on ecocriticism, which issues a radical questioning of human-nature relationships and human practical and creative control of nature. Ecocritical literature challenges and subverts the cultural-creative ways through which nature-human binaries are formulated for the sake of exerting and continuing human supremacy and dominance over the natural world.

So, ecocriticism is, if seen in this light, a subversive revisit, re-intervention and redefinition of nature-human relationship, their influence and dependency and, most importantly, their potentials to harm and help each other. As Richard Kerridge defines ecocriticism as an "environmental ideas and representations" occurring in literature or any other creative-cultural domains and embraces evict a debate and a praxis against cumulative "environmental crisis." (1998, p.5) So what it transpires from here is that it is not a passive cultural criticism and not limited to environment and geography only, rather it is a political praxis which inclusively deals with every cultural space where environment or nonhuman world is treated from broad theoretical and philosophical stances.

Lawrence Buell (2001, p.20) maintains almost that ecocriticism studies of the literature- environment interface and upholds a definitive "commitment to environmentalist praxis." Cheryll Glotfelty's views it as the scholarship the "relationship between literature and the physical environment" that involves a wider politics of activism. Like some other political theories pertaining to literature, for example among other ones feminism, Marxism and postcolonialism, ecocriticism takes a political or "earth-centred approach to literary studies." (1996, p.xix) Simon Estok (2011, pp.16-17) offers almost an identical conception of ecocriticism: it is not limited to theorise nature-literature relationships. For him, ecocriticism is a political praxis that aims to "effect change by analyzing the function - thematic, artistic, social, historical, ideological, theoretical, or otherwise-of the natural environment, or aspects of it" represented in literary or cultural discourses that urges to act responsibly for the natural environment. He has coined the term "ecophobia" to indicate the practice of "imagining badness in nature and marketing that imagination" through hateful cultural and creative recognitions of nature. For instance, it has been an oft-seen representation for nature is that it is "an angered mother" which has been shaped predominantly by creative-cultural representations of nature, for instance in Shakespearean plays, and by the prototyped Western colonial discoverers. (Estok, 2011, pp.1-16) Eventually dominance and subjugation of nature have been made possible by industrial revolution and imperialism.

Controls on nature in the name of winning ecophobia result in commercialization and commodification through nature. So, an ecocritical text interrogates all fallacious creative-cultural representations of nature and nonhuman beings 
out of which nature and nonhuman beings have been debased and destroyed for the progress of the human world. To Greg Garrard, ecocriticism "green moral and political agenda" (2004, p.3) that subversively pinpoints the ways ecological afflictions have been perpetrated by human world for economic pursuits and raises the political pronouncements on eco-consciousness and eco-justice. Ecocritical texts unearth different socio-economico-political phenomena and their impacts on global nonhuman world. Industrial Revolution, colonialism, different destructive wars and capitalism have paved the ways for Western marketisation or commodification of nature: nature has turned out to be an objective machine or resource centre which would be controlled to get maximum services for multiple Capitalist purposes. So to put in an inclusive term, ecocriticism is a political praxis to fight all ecological humiliations and to call for an eco-politics in the face of human practices of controlling and commodifying nature.

\section{Post-humanism as It Is Pertinent to Ecocritical Study OF Literature}

Posthumanism co-relates ecocriticism in terms of its non-anthropocentric challenges to human-nonhuman divides and human superiority determined by this divides or binaries. It investigates how human beings have been philosophically backed up by Renaissance-enlightenment ideals, leading them to wield an all-encompassing dominance on the nonhuman world. Although the nonhuman world is altogether independent of the human world, it is rendered vulnerable and controlled only for the sake of yielding economic and political profits from it. Developed strongly around the 1990s, posthumanism dismantles all cultural and civilising logic and discursive tricks out of which human superiority has been cemented and subjection of natural or nonhuman world has been validated. It dismisses all misconceptions brought against it, for example, its radical critique of human shortcomings, exploitive attitudes toward nonhuman world, and its alleged misanthropy or theoretical anti-human stances.

Carry Wolfe's studies on posthumanism fits quite pertinently here in confronting these debates. According to Wolfe, posthumanism urges human world to intervene on its "taken-for-granted" status of "Homo sapiens", by "recontextualizing" the abstract designation of supremacy "in terms of the entire sensorium of other living beings" who are responsible for the "evolutionary" process birth of entire humankind (Wolfe, 2009, p. xxv). She also argues how human normative and ideological biases of superiority formation and nonhuman suppressions have gone unchallenged in the previous creative-critical humanist traditions. Citing Carry Wolfe, Smart and Smart (2017, p.4) posits: "The humanist attitude relies on the humanity-animality dichotomy, defining each in terms of the other. Becoming human is thought to be "achieved by escaping or repressing not just [our] animal origins in nature, the biological, and the evolutionary, but more generally by transcending the bonds of materiality and embodiment altogether". It not only questions humanist ideal of the humans, but debunks the humanist fallacy that "the proper study of mankind is man" (Thoreau, 1962). Likewise, it casts a doubt that human existence in all sense is a mere incompleteness without nonhuman beings.

\section{DisCUSSION AND ANALYSIS}

\section{A. Ecocritical and Animal Studies Perspectives in Only the Animals}

The foundations of our civilisation lie deeply in a dependence and domination on our natural or nonhuman world. The nonhuman beings served our total sustenance but they did not need to depend on our human world. Even so, human world never ceased to control and abuse the nonhuman world, they rather moved ruthless on the nonhuman beings in the way to produce and reproduce their practical powers through domistication, destruction, and consumption of nonhuman beings. As Jared Diamond (1997, p.125) traces back this history of human control on nonhuman world:

“... plant and animal domestication meant much more food and hence much denser human populations. ... Hence the availability of domestic plants and animals ultimately explains why empires, literacy, and steel weapons developed earliest in Eurasia and later, or not at all, on other continents. The military uses of horses and camels, and the killing power of animal-derived germs, complete the list of major links between food production and conquest."

Human beings have not only ensured their sustenance and development out of the non-humans, but inflicted constant violence and destruction upon their habitats and lives. Animals and the larger nonhuman beings have been utilised for human development. On the other hand, human development has always included the advancement and advantage of the human beings. It has never entailed the vision of welfare of the nonhuman beings.

A social anthropologist, Dovey showcases her cross-disciplinary take-on of a unique literary form lending a metafictional and intertextual feel to each story which pivots around a thought-striking animal-questioning on the meanings of humanity, rationality, autonomy and linguistic ability inculcating "a relocation of human-nonhuman bounderies" (Nayar, cited in Dönmez 2016, p.114 ). Tongue-in-cheek but tragic, "A Letter to Sylvia Plath", an epistolary story, sketches a dolphin with her letter to Sylvia Plath, frequently alluding to Plath's husband Ted Hughes's animal poems. In a passionate vein, she shares her agonies “-I don't think you will mind Ms Plath - you understood the cathartic uses of a good cleansing female rage." Epiphanic, she continues, "But I must tell you how I lived, and how I died, in order to keep my place in this modern menagerie of animal souls." (Dovey 2014) This is elegiac and gruesome to discover the magnitude of a dolphin's life crises. 
We encounter all these phenomena in Only the Animals. As in the first story "The Bones", the camel poignantly recollects: "I too have ghosts in my past, I wanted to tell Henry Lawson. The ghosts of the other camels who were shipped with me from our birthplace on the island of Tenerife, sold along with our handlers-who had come from somewhere else far away - to an English man on his way to Australia." (Dovey, 2014) The existential dislocation of the animals is represented here by a camel. It continues the terrible atrocities wrought upon it by the frontier battle of Australia: "But I do exist, I thought. I may have oval red blood cells, three stomach compartments, and urine as thick as syrup, but I exist. ... . Homesick." (2014) These kinds of posthumous self-tales of ten animals strongly connect a radical dimension to this text. This is essentially the main theme of ecocriticism and animal studies. Like these two theoretical disciplines, this book questions, challenges and unsettles man-animal dichotomy and its resultant evils faced by the animals. As Sarah Mcfarland's (2015, p.152) holds: "Within ecocriticism, critical animal studies interrogates the human-animal aspects of the self/other binary and the arising consequences to subjectivity and species definitions."

The ten wars concerned in this book have been historically documented only in terms of human losses. The ten animals who were killed in those wars have not been recorded in any history. Dovey's fiction brings out their voice to share their tales which have remained unheard always. This aspect of human mindlessness about the non-humans is a major area of investigation for animal studies and ecocriticism. As Phillips (2010, p.1) notes ecocriticism and animal studies deal with "harm and degradation" done against all natural beings and the "abusive private ownership" of them. He further observes that both of these complementary disciplines undertake "the interpretation of animal behavior, especially of animal consciousness, communication, and emotion, and the implications of this interpretation for animal rights; the ecological centrality of animals in the habitats where they have evolved, and from which too many of them have been removed; the disruption of both animal and human lives ... the ethics and the politics of human-animal relations"(2010b, p.1)". Ceridwen Dovey's Only the Animals (2014) and John Coetzee's The Lives of Animals (1999) strongly involve these ecocritical and animal studies insights. For instance, in Dovey's story "Psittacophile" a parrot relates: "I began to screech for hours on end. I stopped eating, ignored my toys, and bit her to the bone when she tried to take me out of my cage. She watched in despair as I self-mutilated, ripping out my own plumage, plucking myself bare. My feathers accumulated in layers on the floor of my cage." (2014) This story unveils how the ownership of animals as pets involves a brutal selfishness and apathy out of which human beings use and abuse animals as some fashion items. This is a trauma-tale that shows how human world in sustaining its unscrupulous authority over the natural world has neither empathised with nonhuman beings, nor have they heard animal or nonhuman beings' traumas and tragedies. The paper here attaches Animal Studies, in this regard, to trauma studies, because both of them expose, as Kari Weil observes (2012, pp.3-4), "the violence done to animals and their habitats (what indeed has been called a genocide) and the difficulty of assessing how animals experience that violence. Both raise questions about how one can give testimony to an experience that cannot be spoken or that may be distorted by speaking it."Only the Animals explores the age-old stories of animal sufferings and subversively repudiates existing norms and forms of animal or nature narratives which vindicate and validate human creative treatment of the nature-cultures. Moreover, this book unearths "stories about human relationships" with mother nature which follows an intriguing philosophy of "perspectival multinaturalism", as termed by Brazilian anthropologist Eduardo de Castro, which instills into children a logic that our existence is dependent on different nonhuman and human entities to whom we must be responsible. (cited in Adamson, 2014, p.173) Thus, it hints at unsettling human world's creative and practical ways of being existent through controlling, abusing and exploiting the nonhumans.

\section{B. Posthuman Reflections in Only the Animals}

To probe the posthuman aspect of the book, Harari's (2017) recent studies on human incompleteness and lack of selfsustaining vitality deserve attentions: "Homo sapiens rules the world because it is the only animal that can believe in things that exist purely in its own imagination, such as gods, states, money, and human rights." Human beings enjoy an all-encompassing superiority out of which they exert a taken-for-granted power in defining themselves as an absolute subjectivity and non-humans as the incomplete and base beings. The consequences of these othering binaries contribute to both physical and ontological threats for the non-humans. Only the Animals dismantles and challenges, though sardonically, these constructs of human supremacy. This angle of the book sets a posthuman resonance. For instance, the epigraph of the story "Hundstage" reads: "Those who are humane toward animals are not necessarily kind to human beings". (Boria Sax, cited in Dovey, 2014, p.75) Dovey pushes forward some fundamental criticisms on human violence which human beings have shaped as an inevitable means of its survival and development.

The first question she poses is very subversive: If humans are not safe for their own race, how can they protect other beings? The ten wars concerned in this text and the plights of both human and non-human worlds due to these wars reveal how brutal human beings actually are. This elicits her second question about the validity of human pride in claiming to be the so-called supreme creation of the world. The question is quite straight-forward: If harming and humiliating nonhuman world is the sole way to survive, what is the point of pride then as the so-called sublime beings? All ten animals of this fiction expose this posthuman radical interrogations of human glory of being the Homo sapiens. Animals are deemed as lesser subordinates as they lack intelligible language. In the face of this humanist egotism, Dovey has placed a counter-discourse by putting language in their tongue. As we encounter the dolphin's radical questionings on human beings from the story "A Letter to Sylvia Plath": 
"Humans might be conscious thinkers; we are conscious breathers. It is very easy to choose to die if every breath is a matter of choice. I am not the first dolphin to suicide, nor will I be the last. one to take killing a human very hard. It is as taboo for us as killing our own babies. We recognize in you what your ancients used to recognize in us and understood as sacred a long time ago, when killing a dolphin was punishable by death. You used to think of us closer the divine than any other animal on earth, as being messengers and mediators between you and your gods. You honoured us with Delphinus, our own constellation in the northern sky." (Dovey, 2014)

This is where the paper attends to Pramod Nayar's $(2013,11)$ term "critical posthumanism", which signals a "radical decentring of the traditional sovereign, coherent and autonomous human in order to demonstrate how the human is always already evolving with, constituted by and constitutive of multiple forms of life and machines. Literary texts that have since the Renaissance always shown us how humans behave, react and interact - indeed it has been said that literature 'invented' the human - have now begun to show that the human is what it is because it includes the nonhuman." Dovey upholds this posthuman turn: the animals are placed at the centre to make us hear how generously they have served the humans and how, in return, they have been harshly wronged by the humans. This is even present in the creative practices human world has undertaken with the help of animal presence. The chimpanzee of the story "Red Peter's Little Lady" comes up with a counter-blow against all human hypocrisies and lessons of human creative artefacts shaped on and with animal imagery:

"I am itchy. Itchy, itchy, itchy. Frau Oberndorff won't let me scratch. She bathes me, combs my hair to make it lie down, cuts my toenails, cleans my tear ducts. She says my breath is a problem. It stinks. I like the stink.

$\cdots$

I breathe out and sniff it in. . . . I scratch my bum, sniff my fingers. (Dovey 2014)

Hazel candidly denies the human constructs of 'decorum' and hygiene. As the epistolary love-making between she and Red Peter goes on, she tells Red Peter: "I cannot give you much other than a warm body flexible in the ways you would like it, a certain length of arm, bow legs, a barrel torso." She further says: "Would you like me to be more human, or less human, or more or less human?" (Dovey, 2014). He we encounter a sardonic attack on human boastfulness as the best creature of the world.

The paper adds Dovey's radical renarrativizing of the human world to Noah Harari's world-view shattering discourse on the failings and inadequacies of human existence:

"As far as we can tell from a purely scientific viewpoint, human life has absolutely no meaning.

Humans are the outcome of blind evolutionary processes that operate without goal or purpose. ... if

planet earth were to blow up tomorrow morning, the universe would probably keep going about its business as usual. As far as we can tell at this point, human subjectivity would not be missed." (Harari 2014, p.331)

To elude this danger of existential vulnerability or weakness, humans have drawn distinctions or binaries between themselves and nonhuman beings. They have, with their cultural constructs and ideologies, exalted them above nonhuman beings and put nonhuman beings into some fixities and stereotypes to stand for them and to serve them perpetually.

Dovey not only advocates a critical empathy through her animal narratives, but questions the literary and philosophical injustices done upon the animal world. The ten animals of Dovey's ten stories invoke ten authors who wrote extensively with animal imagery and became famous. None of these authors, from George Orwell to Henry Lawson or Ted Hughes, could accommodate the animal question as a distinct one and hold the animals as a complete being. They rather retained traditional humanist legacy of human vitality in every way possible by denying the nonhuman beings' very existence. They used animals to configure their literary creations by keeping alive man-animal binary which helped them and their artefacts. As the dolphin in "A Letter to Sylvia Plath" relates:

"I began by rereading the work of your ex-husband, the British poet Ted Hughes, thinking I might be inspired by him. ... Back then, I had admiringly thought he was trying to understand the human by way of the animal, but now I can see that in fact he wanted to justify the animal in the human" (Dovey 2014).

This is how the non-humans have been made to cater for the humans physically and creatively either for their material help or for their creative embellishments. In philosophy, we see these same biases of binary relationship which sustain human-made delusion of supremacy. Cary Wolfe has shown how Hegelian-Kantian human ideals have contributed to establish humanism. The posthuman discourse, like Only the Animals, subverts this kind pro-human and anti-animal construct. Wolfe posits that animal rights in terms of having an egalitarian treatment in our creative-critical world have been sheerly neglected by all philosophical or literary canons. As Wolfe (2003, p. 203) observes,

"[Animal rights] in philosophical frame remain an essentially humanist one in its most important philosophers (utilitarianism in Peter Singer, neo-Kantianism in Tom Regan), thus effacing the very difference from the animal other that animal rights sought to respect in the first place."

As war-critiques, every story of the book shows how war has been validated by humanist and cultural traditions of will-to-power motifs that have resulted in an imperialist commerce and devastating consequences for the nonhuman world. Moreover, the humanist traditions of philosophical construction of human beings as the most supreme creation, 
(Homo sapiens) and, self-protective force (Homo polemos), and most potentially thinking existence (cogito ergo sum) as propounded by Descarte's and Heraclitus's versions on human beings, have propelled a negation of the identity of a distinct being for the animal or nonhuman existence, and reinforced an aggressive exercise of human "will to power" over nonhuman world. The way of colonialization has been validated by this epistemology of war and hence, can be linked with human interventions and subjugations of natural and nonhuman world. Both of these ways are driven by human motifs of power and supremacy over weaker worlds and "in this paradigm of war", as Sabello Ndlovu-Gatsheni posits (2016, p.41), human beings have been established "as 'homo polemos' (warrior, war-maker) whose humanity cascades from" a philosophy-backed paradigm of war; that is, "I kill, therefore I am" (Sonderling, cited in NdlovuGatsheni , 2016, p.41).

These stories capture the dynamics of domination and destruction by which human world declines its existential dependency on natural and nonhuman beings. Dovey's trajectory of nonfictional ten wars and ten fictional animals murdered in the ten wars strongly reveals human inclination for fast material output or power through causing changes to and violating their inherent bonds with other beings and species which ensure human beings' very existence. Alain Badiou (2006, p.38) critiques on these aspects of human propulsions and actions for quick advancements and gains:

"Our world is marked by its speed: the speed of historical change, the speed of technical change, the speed of communications, of transmissions, and even the speed with which human beings establish connections with one another. This speed exposes us to the danger of a very great incoherency. It is because things, images and relations circulate very quickly that we do not even have the time to measure to what extent all that is incoherent. Speed is the mask of inconsistency. Philosophy must propose a slowing down process."

Nonhuman beings are the first victims of the change-driven human world. All these speedy growth of material development and change have worked for sustaining human power over other the nonhuman world and triggered a violent means of war, as projected in Dovey's book, of retaining human world's power and dominance.

\section{Narrative Revisioning through an Animal Poetics}

Dovey's non-traditional narrative perspectives including her intermingling of posthumous animal narrative voice, allusion to some popular authors of animal literature and non-adherence to any formulaic storytelling, i.e., linearity of plot, realist trends of setting and characterisation, advance strong challenges to the modernist storytelling artifices. Not set in particular locations, the setting navigates from the US to colonial Australia, from Pearl Harbour to Sarajevo, from Russia to Mozambique and from Beirut to Germany. The wars or human conflicts span from the frontier wars of Australia to American invasion in Iraq, from the seize on Sarajevo to World War I, from World War II to Arab-Israel war, from Cold War to civil war in Africa. They hark back the readers to different junctures of violence, deaths and destructions. Thus, this nonlinear timeline of her stories represent the immanence of human brutality in every part and era of the world.

All the ten fractured but interwoven tales are presented in some postmodern narratives. All these stories being derived from different personas, settings and nonhuman sufferings represent a "pastiche and collage" (Kvale 1995a, 23) of juxtaposing diverse animal voices. The radically unique ways of bringing these voices of sufferings are themselves "a renarrativisation" $(\mathrm{b}, 21)$ or counter-assertion of the animals who have been forgotten by human history and literature. Dovey's ten animal characters, the alter egos of all the marginalised nonhumans, stand out to pronounce a counter-tale of heroism and optimism. Unlike modern fiction, Dovey's fiction is marked by an optimism stating that "mourning process is completed" because "legitimation can spring from" the nonhuman world (Lyotard 2002a, p.141). Postmodern narratives, Dovey's stories bring back the "destructured, decentered, and dehumanised" (Klages, 2002, p.165) nonhuman or animal identity. Moreover, these stories can be seen as some "micro-narratives" (Lyotard, 2004b, pp.130-31) on the misery, death, dislocation and alienation of the nonhuman beings and animals, who have hardly been empathised with and acknowledged by the human world. Animals' questionings of human oppressions on the them pitted Dovey's animal stories against the "meta narrative apparatus of legitimation" (Lyotard 2004,123-124) of human language, literature, rationality, power, politics, development, human rights, dominance and so on, which have caused the existential erasure of all nonhuman beings throughout history.

Again, these stories are some ironic but subversive "language games", which allow the cat, parrot, dog, tortoise and other animal characters to be in a newly shaped individual "nodal points" or "communication circuits", transcending the grand projects of human literature and cultural gaze on the nonhuman beings. A counter-anthropocentric mode of narrative, these stories signal that a new cultural wholeness is in the offing which is an impossibility without ensuring creative and practical world's justice towards the nonhuman world. All these animal stories have "non-hierarchical, heterogeneous, multiplicitous, and acentered" (Gartler 2004) narratives in terms of the spatiality and temporality of the action of the stories. Told posthumously by the dead animals, these stories have a postmodern mode of narrativising the nonhuman brings of different parts of the world as autonomous "individuals", who have been "defined only by their state at a given moment--such that the local operations are coordinated and the final, global result synchronised without a central agency" (Deleuze and Guattari, 1987, 21). These postmodern stories are like "double-coded" architecture or art in which "no style dominates; instead "endless improvisations and variations on themes; parody and playfulness" (Jenks, 1995, 10) navigate around so many narrative styles animal voices and places. All animal characters are held with significant attention and thus, they signify a cultural wholeness that postmodernism celebrates. Instead of sticking 
to any dominant genre and form of fiction and settings and characters these stories advance a "deterritorialisation" (Deleuze and Guattari, 2002, 165) of human-centric storytelling which involves nonhuman-human inclusiveness or a democracy, that is; "at root to be is not to be one but to be diverse" (Gutting, cited in Drolet, 2004, 28). Besides, the ten animals do not conform to and plead to existing human creative-practical world for assuring justice to the existential harms that have been perpetrated on the nonhuman beings. They instead poke questions to human practical and creative dependency and violence on nonhuman beings. They urge human gaze to be thoughtfully revisioning their ways of claiming to be the Homo sapiens of the world. Dovey's radical newness in narrativising these animal-centred animal tales marks a subversion of the exisiting creative-critical anthropocentrism.

Dovey travels with fluidity between different times, places and people. All of them initially sketch a fighting form of life but eventually turns out to be a depiction of supreme optimism of life through struggle and resilience of a shared happiness. The camel killed in the frontier battle of colonial Australia in 1892, the blue mussel in Pearl Harbour, the cat in World Word I, a bear died of starvation in the siege of Sarajevo in 1992, a dog in the Eastern Front in World War II, a dog in the bombing of Beirut in 2006, an ape in Germany during World War I, a tortoise in Russia during the Cold War in 1968, an elephant in the 1987 civil war in Mozambique and a dolphin in the US invasion on Iraq in 2003 constitute a multi-vocity of animal tales. The disparate time and space and types of the murdered animals manifest the ubiquity of human violence on animals. Thus, her renarritivisation brings in post-human interrogation on how anthropocentric world system and its humanist traditions of literature have exerted relentless violence and destruction as a means of exhibiting political and creative power and dominance.

Dovey ironically utilises the intertextual elements of her book: by drawing attention to authors who have written on animal issues she has subverted the inadequacy of a critical empathy lying in their animal literature and interrogated the very notion of animal literature. These animals are shown to be paying acknowledgement to human creative efforts, however little they are, to depict nonhuman and human world's infinite suffering. As Dovey mentions in her website:

"Each of the animals also pays homage to a human writer who has written imaginatively about animals during much the same time span, from Henry Lawson to Ted Hughes, from Kafka to J.M.

Coetzee, from Colette to Virginia Woolf, from Tolstoy to Jose? Saramago, from Gunter Grass to Jack

Kerouac, from Tom Stoppard to Julian Barnes.” (nd)

Dovey through her animal narrators has brought in the sheer commodification and utilisation of animals and their sufferings in literature and creative artefacts. This is tantamount to a creative violence and this form of animal literature has failed to eliminate human apathy to nonhuman beings. As we encounter in the story "Plautus: A Memoir", the soul of the tortoise cites poet Czeslaw Milosz and grieves: "So little of the total suffering, human or animal, can ever make its way into literature in the end. When it does, we should pay attention, and pay our respects." (Dovey 2014) These animal articulations press a counter-necessity to accommodate nonhuman voice in human creativity.

Intertextuality, which "challenges both closure and single, centralized meaning" (Hutcheon 1988, p.127), informs this book significantly about its ways of interrogation of realist narrative styles of modern literature and the lack of inclusivity or cultural wholeness in modern history. In her acknowledgement notes Dovey with a self-reflexive voice attests her narrative queerness:

"Given that the stories in Only the Animals pay homage to many authors who have written about animals, I am indebted both directly and indirectly to multiple works of literature. Many of the animal narrators intentionally use words, phrases and sentences taken verbatim from the work of other authors." (Dovey, 2014, 248)

These elements of "self-consciousness and irony" (Jenks ,1995, p.27) on past memories and moments find powerful rendering in her stories and resonate that past still "seems to have some validity". She serves dual purposes with her ironic deployment of inter-textuality: on the one hand, she figures out a vast oeuvre of literature that has been written by using nonhuman beings, on the other, through the animal narrator-characters she unveils the sheer anthropocentric nature of animal literature and the commodification of nonhuman beings in literature written to date.

\section{CONCLUSION}

This brings the paper to its conclusion that human-centric world for its cultural and economic productions have been solely reliant on the nonhuman world. The dog, camel, parrot, bone, and other deceased animals of Dovey's Only the Animals emblem human world's violence against nonhuman world and human violation of nonhuman rights. But human world has normalised that it is the rights of human beings to kill and control nonhuman beings because their powers or abilities of language, rationality, reason and civilisational practices have rendered them, as claimed and licensed by religion, science, philosophy, literature and such human superstructural knowledge, superior to nonhuman beings. These binary-making agencies of human world of production and superstructure have utilised nonhuman world's benignity and helplessness as a vested property for humans. Again, nonhuman beings' inabilities of language and reason have rendered them passive and vulnerable in their power relation with human beings. Nonhuman beings are not vocal with creative or cognitive powers. But it does not prove that their lives are to be seen as dead or passive or some base objects and as something, but not somebody, which do not have the potentials of agonies, pains and sufferings. Dovey's book, with its strong undertones of ecocriticism and posthumanism, strive to bring these animalempathy to the fore by erecting them as some vocal, vigorous and radical voices to unveil human world's destructive 
and exploitive violence against the nonhuman world. I can resort to Jeremy Bentham's (2007) philosophical conviction on animal welfare here:

"But a full-grown horse or dog is beyond comparison a more rational, as well as a more conversable, than an infant of a day or a week or even a month, old. But suppose they were otherwise, what would it avail? The question is not, Can they reason? nor Can they talk? but, Can they suffer?"

Bentham's dog or horse and Dovey's ten animals represent the world of the nonhuman beings which has been brutalised and set to cater for consolidating the significance and supremacy of human survival. The paper accentuates this note of pro-animal sensitivity and politics which radicalise the animals or any nonhuman existence with a genuine call for taking the animal question more seriously. Moreover, it also posits a counter-discourse on animal vitality and, of course, for revising human-animal binaries. The paper responds to and agrees with Dovey's posthuman and ecocritical association in a serious light: human view on human supremacy and nonhuman inferiority is a violation of nonhuman beings' existential rights. It also posits, through war critiques, that humankind's violence is not only endangering animal or nonhuman lives, but in turn, humans are converting the human-nonhuman world into a disastrous world. A world with indeterminate injustice and murder upon animals will lead the world to destroy its ecological balance which cannot be reinstated by any human agentive means, i.e., science, human rights, development and politics and so on.

Australia was afire, leaving indeterminate number of animals gutted by fire, dislocated from their abode and wounded badly. Animals suffered the same brunt of human brutality when Amazon has lately been aflame. Australia's wildlife or Amazon's nonhuman beings or Dovey's ten animals are a significant reminder for the human world which competes with its own members to grab power and control by using, abusing, manipulating and demolishing the nonhuman world order. It is more than a high time human world questioned its unscrupulously decided superiority and held its abiding saviour and existence-maker, i.e, nonhuman and natural world, with compassion and justice. This paper, despite concentrating on a little part of Only the Animals, adopts a fresh critical look into Dovey's far-reaching animal narratives with an eclectic treatment of posthumanism, postmodernism, ecocriticism and animal studies. Dovey's Only the Animals is a rigorous scholarship on the insecurities and genocides animals or broader natural environments are undergoing every day. As Dovey herself vindicates in her website: "Only The Animals asks us to find our way back to empathy not only for animals, but for other human beings, and to believe again - just for a moment - in the redemptive power of reading and writing fiction." (nd) This book, keeping this undertone, hence, espouses a political praxis to fight for animal or environmental welfare by subversively calling into question human superiority, power paranoia, and, quite notably, human creative-critical apathy and exploitation, as reflected by Dovey's invoked authors who have written with animal subject-matters, over the broader natural environments.

\section{ACKNOWLEDGEMENTS}

I acknowledge that this article is developed, with moderations, out of a short thesis and assignment, done with two units of my coursework studies in Writing and Literature at Deakin University, Australia, on Ceridwen Dovey's fiction, Only the Animals. I have used APA (latest edition) reference style.

\section{REFERENCES}

[1] Adamson, J. (2014). Environmental Justice, Cosmopolitics, and Climate Change. In (ed.) Louis Westling. The Cambridge Companion to Literature and Environment. New York: Cambridge University Press.

[2] Anderson, W. T. (1996). The Fontana Postmodernism Reader. London : Fontana Press.

[3] Badiou, A. (2006). Infinite Thought: Truth and the Return to Philosophy. Trans. and ed. by Oliver Felthamand Justin Clemens. London: Continuum.

[4] Bentham, J. (2007). An Introduction to the Principles of Morals and Legislation, New York, Dover. doi: 10.1093/actrade/9780198205166.book.

[5] Buell, L. (2001). Writing for an endangered world: Literature, culture, and environment in the US and Beyond. London: The Belknap Press of Harvard University Press.

[6] Callus, I. (2014). Exhausted Replenishment: Experimental Fiction and the Decomposition of Literature. Word and Text: A Journal of Literary Studies and Linguistics, IV: 1:119.

[7] Dale, L. (2014). "Review: Only the Animals by Ceridwen Dovey". Animal Studies Journal 3(2).

[8] Deleuze, G. and Guattari, F. (1987). A Thousand Plateaus: Capitalism and Schizophrenia. Minneapolis: University of Minnesota Press.

[9] Derrida, J. (2008). The Animal That Therefore I Am. New York: Fordham University Press, 48.

[10] Diamond, J. (1997). Guns, Germs, and Steel: The Fates of Human Societies. London: Vintage.

[11] Dönmez, B. A. (2016). Recent Approaches in the Posthuman Turn: Braidotti, Herbrechter, and Nayar. Relations. Beyond Anthropocentrism. 4 (1). http://www.ledonline.it/index.php/Relations/article/download/996/801.

[12] Dovey, C. nd. https://www.ceridwendovey.com/books/only-the-animals/.

[13] Dovey, C. (2014). Only the Animals, Melbourne: Penguin.

[14] Drolet, M. (2004). "Introduction”, The Postmodern Reader: Foundational Texts, London: Routledge.

[15] Estok, S.C. (2011). Ecocriticism and Shakespeare: Reading Ecophobia. New York: Palgrave Macmillan.

[16] Foucault, M. (1973). The Order of Things, trans. Alan Sheridan. New York: Vintage.

[17] Gartler, M. (2004). 'rhizome', Theories of Media, University of Chicago, https://csmt.uchicago.edu/glossary2004/rhizome.htm 
[18] Garrard, G. (2004). Beginnings: Pollution, Ecocriticism. (ed.) London :Routledge.

[19] Glotfelty, C. and Harold, F. (1996). The Ecocritical Reader: Landmarks in Literary Ecology. (ed.) Athens: The University of Georgia Press.

[20] Harari, Y. N. (2017). Yuval Noah Harrari personal website. https://www.ynharari.com/book/sapiens/.

[21] Harrari, Y. N. (2014). Sapiens: A Brief History of Humankind. London : Vintage.

[22] Haraway, D. (2018). "Ethics Explainer: Post-humanism ”, issue no. 22 February 2018. https://ethics.org.au/ethics-explainerpost-humanism/.

[23] Haraway, D. (2008). When Species Meet. Minneapolis: University of Minnesota Press.

[24] Herman, D. (2012). 'Toward a Zoonarratology: Storytelling and Species Difference in Animal Comics', In: Narrative, Interrupted: The Plotless, the Disturbing and the Trivial in Literature, Berlin: De Gruyter.

[25] Jencks, C. (1996). Part Two: What is Postmodernism?, The Fontana Postmodern Reader, edited by Walter Truett Anderson, London: Fontana Press.

[26] Klages, M. (2002). Literary Theory: a Guide for the Perplexed, London: Bloomsbury Publishing Plc, ProQuest Ebook Central https://ebookcentral.proquest.com/lib/deakin/detail.action?docID=742898.

[27] Kvale, Steinar. (1996). Part One: Themes of Postmodernity. The Fontana Postmodern Reader, ed. Walter Truett Anderson. London: Fontana Press.

[28] Kerridge, R., and Neil S. (1998). Writing the Environment: Ecocriticism and Literature. (ed.) London: Zed Books.

[29] Langdon, J. (2016). Review of Only the Animals by Ceridwen Dovey, Mascara Literary Review, 7 September, Reviews/ Essays.19. http://mascarareview.com/jo-langdon-reviews-only-the-animals-by-ceridwen-dovey/.

[30] Lyotard, J. (2004). Part Two: "from The Postmodern Condition: A Report on Knowledge", The Postmodern Reader: Foundational Texts, London: Routledge.

[31] Moore, S. (2014). Divinanimality: Animal Theory, Creaturely Theology. (ed.). Bronx: Fordham University Press. ProQuest Ebook Central. Created from deakin. (accessed December 22, 2019).

[32] McFarland, S. E. (2011). Part ii: 'Animal Studies, Literary Animals and Yann Martel's Life of Pi'. In: The Cambridge Companion to Literature and the Environment, edited by Louise Westling, New York: Cambridge University Press.

[33] Nayar, P. K. (2013). Posthumanism, Cambridge: Polity Press, ProQuestEbookCentral. http://ebookcentral.proquest.com/lib/deakin/detail.action?docID=1729549.

[34] Ndlovu-Gatsheni, S. (2016). Decolonial Theory of Life. The Decolonial Mandela: Peace, Justice and the Politics of Life. (1st ed.). New York: Berghahn Books.

[35] Phillips, D. (2010). Introduction: Special Issue on Animal Studies and Ecocriticism. Safundi: The Journal of South African and American Studies, 11:1-2, 1-2, DOI: 10.1080/17533170903458355.

[36] Smart, A., \& Smart, J. (2017). Posthumanism : Anthropological insights. ProQuest Ebook Central https://ebookcentral.proquest.com

[37] Sullivan, H. I. (2014). 'The Ecology of Colors: Goethe's Materialist Optics and Ecological Posthumanism'. In: Material Ecocriticism, Bloomington: Indiana University Press.

[38] Thoreau, H. D. (1962). The Journal of Henry D. Thoreau, edited by Bradford Torrey and Francis H. Allen, New York: Mineola.

[39] Walsh, S. K. (2015). The Art of the Steal: Fiction by Ceridwen Dovey and Valeria Luiselli. Virginia Quarterly Review, Fall. 212-216.

[40] Weil, K. (2012). Thinking Animals: Why Animal Studies Now? Columbia University Press, ProQuest EbookCentral. http://ebookcentral.proquest.com/lib/deakin/detail.action?docID=909567.

[41] Wolfe, C. (2003). Zoontologies: The Question of the Animal. (ed.) Minneapolis: University of Minnesota Press.

[42] Wolfe, C. (2009). What is posthumanism?. ProQuest Ebook Central https://ebookcentral.proquest.com

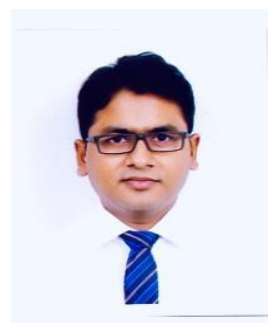

Habibur Rahaman teaches English language and literature in English at Bangabandhu Sheikh Mujibur Rahman Science and Technology University, Bangladesh. He completed his Bachelor of Arts in English language and literature in 2010 and MA in literature in English in 2011 from the University of Dhaka, Bangladesh. Lately he has completed his Masters of Arts in Writing and Literature from Deakin University, Melbourne, Australia. His research interests navigate around decolonisation, environment and literature, curriculum studies and unschooling or open literacy and its alignments with children's literature and identity. 